\title{
COMMENTARY
}

\section{India's Energy Strategy for Inclusive Sustainable Development}

Kirit S. Parikh *

\section{INTRODUCTION}

While energy is critical for economic growth, it is also a crucial factor in improving the quality of human development. Energy does not comprise only electricity; it also includes fuels used for cooking and mobility. Energy use has led to much environmental and ecological degradation: air pollution from the use of fossil fuels, land degradation due to coal mining, and deforestation resulting from hydro development. Moreover, burning fossil fuels contributes to climate change. India aspires to be a global economic power that balances inclusive growth for human development and the challenges of pollution and climate change.

In view of the COVID-19 pandemic, the need for inclusive growth has become even stronger. India's energy strategy has to help fulfil these aspirations.

\subsection{The current energy scene}

In 2018, the Indian economy consumed a total of 809 million tonnes of oil equivalent (Mtoe) and 1,547 billion-kilowatt hour (BkWh) of electricity. That same year, in per capita terms, China's consumption of electricity was nearly five times that of India.

India imports all major fossil fuels. In 2019-20, 87\% of crude oil (227 million tonnes $[\mathrm{MT}]$ ) used in the country was imported. However, the net export of petroleum products was 22 MT (PPAC n.d.[a]). Thus, nearly $80 \%$

\footnotetext{
* Integrated Research and Action for Development (IRADe), C-80, Shivalik, Malviya Nagar, New Delhi - 110017, India; kparikh@irade.org.

Copyright (C) Parikh 2020. Released under Creative Commons Attribution-NonCommercial 4.0 International licence (CC BY-NC 4.0) by the author.

Published by Indian Society for Ecological Economics (INSEE), c/o Institute of Economic Growth, University Enclave, North Campus, Delhi 110007.
}

ISSN: 2581-6152 (print); 2581-6101 (web).

DOI: https://doi.org/10.37773/ees.v3i2.185 
of the country's consumption of petroleum products comes from imported crude oil. In the case of natural gas, India imported nearly $50 \%$ of its domestic requirement. While India's domestic oil and gas resources are limited, it has an abundance of coal. Still, nearly $24 \%$ of the country's total coal consumption was imported.

The 2006 report of the expert group set up by the Planning Commission on Integrated Energy Policy (IEP) notes that extractable coal reserves in India will be exhausted in 35-40 years if coal consumption keeps growing, and, in the long term, India will have to shift to renewable resources such as wind and solar energy (Parikh et al. 2006). As a consequence, and as a part of the National Action Plan for Climate Change (NAPCC) to promote solar power, the Jawaharlal Nehru National Solar Mission was launched in January 2010 with the aim of generating 20,000 megawatt (MW) of solar capacity by 2022 . The government recognized that subsidies for solar power generation in the form of assured feed-in tariffs (FIT) would have to be provided during the initial stages. However, to incentivize efficiency and cost reduction, competitive reverse bidding for the required FIT was initiated. As a result, the required FIT came down from ₹ $13.5 / \mathrm{kWh}$ in 2010 to around ₹2.5/kWh in 2017, and it has further come down to ₹2.36/kWh in June 2020.

\subsection{Energy use and local environmental pollution}

Our current energy use patterns cause a great deal of local environmental pollution. Coal mines degrade the land and cause deforestation. Fossil fuel use causes severe air pollution in our cities. All mines are required to restore the land that they have adversely affected. All firms that cause deforestation are also required to carry out compensatory afforestation and contribute to the Compensatory Afforestation Management and Planning Agency (CAMPA) Fund. Unfortunately, however, the funds remain largely unutilized. Unless the government is serious about it, afforestation is not implemented effectively. Therefore, a better strategy would be to prevent deforestation.

\section{ENERGY POLICIES FOR LOW-CARBON INCLUSIVE SUSTAINABLE DEVELOPMENT}

In recent years, concerns regarding the growing dependence on imports, climate change, and severe air pollution in cities across India, as well as the falling costs of solar photovoltaics (PV), have led to changes in energy policies in India. 


\subsection{Reducing greenhouse gas emissions}

Even before the Paris COP $^{1}$ in 2015 , India had declared its intentions to reduce its emissions intensity by $30-35 \%$ by 2030 (compared to 2005), and to increase the share of non-fossil power generation in the total installed capacity to $40 \%$ by 2030 . The Planning Commission set up an expert group, which I chaired, to examine the low-carbon strategy for inclusive growth (LCSIG). The LCSIG reports (Parikh, Chawla, and Pande 2011; Parikh et al. 2014) suggest various measures to reach these goals: promoting energy efficiency in households, industry, transport, and buildings; emphasizing solar and wind; and substituting imported fuels with locally sourced ones. Subsequently, the government has stepped up its goal to installing $175 \mathrm{GW}$ (gigawatt) of renewable energy capacity consisting of small hydro projects, biomass gasifiers, biomass power, urban and industrial waste power, and solar and wind energy by 2022 .

At the end of March 2020, the share of renewable energy capacity was around $23.5 \%$ of the total generating capacity of 370 GW (Ministry of Power 2020). The share of renewable resources in the energy mix in 2018 19 was less than $8.5 \%$, as renewable resources such as solar and wind do not generate electricity round the clock. Nevertheless, the growth of renewable capacity indicates that India will reach its target of $175 \mathrm{GW}$ perhaps a year or two after 2022. India is also pushing for importing nuclear power. Unfortunately, the construction of nuclear plants takes a long time and is, therefore, expensive. Private foreign investments in nuclear plants also face issues of liability.

\subsection{Measures for inclusive growth}

The goal of inclusive growth is considered non-negotiable by India's policymakers and many in the civil society, and thus it demands the highest priority. For this, a projected $1 \mathrm{kWh}$ of electricity per day per household, six liquified petroleum gas (LPG) cylinders per year per household, 100\% access to electricity and clean water, pucca (durable) houses, education, and health services for all are to be made available by 2030 . This has been the goal of both the present and previous governments. Using their top-downbottom-up model, which maximizes private consumption and provides all these benefits by increasing government expenditure and supplementing income transfer, Parikh et al. (2013) have shown that inclusive growth does not have to sacrifice economic growth.

\footnotetext{
${ }^{1}$ Conference of Parties signatory to the UN Framework Convention on Climate Change proposed at the Earth Summit in Rio de Janeiro in 1992.
} 
The Government of India launched the Rajiv Gandhi Grameen Vidyutikaran Yojana (RGGVY) in April 2005 to provide electricity to rural households. The goal was to electrify 1.10 lakh unelectrified or deelectrified villages and provide free electricity connections to 2.3 crore below poverty line (BPL) households. By April 2012, 1.05 lakh villages had been electrified and free connections had been given to 1.95 crore BPL households. The Modi government stepped up the programme under the name of Deendayal Upadhyaya Gram Jyoti Yojana to connect all households and provide stable electricity supply to all by 2019. While nearly $100 \%$ of households are now connected, the quality of supply needs to be improved.

Along with access to electricity, clean cooking fuels are equally important for well-being. The use of dung, firewood, and agricultural waste as cooking fuel causes severe indoor air pollution, which cause millions of premature deaths annually in India. Smith (2000) estimated that approximately 0.40.55 million deaths resulted due to this cause in the late 1990s. The IEP emphasized the importance of clean cooking fuel in its 2006 report. In 2001 , only $11 \%$ of households used LPG ( $6 \%$ rural; $17 \%$ urban); this increased to $29 \%$ in 2011 (12\% rural; 66\% urban). The IEP recommended the provision of six LPG cylinders per household per year and a subsidy through smart cards as direct benefit transfer (DBT) - this is now the accepted mode as the Modi government has increased the ease of DBT through the expansion of JAM (Jan Dhan, Aadhar, Mobile) (Government of India 2016). LPG customers increased from 137 million in 2011-12 to 257 million in 2017-18 (PPAC 2018). This rise has increased the import of LPG from 5.8 MT in 2011-12 to 13.2 MT in 2018-19.

\subsection{Measures for increasing energy efficiency and security}

Increasing energy efficiency means using less energy to produce the same output. Energy intensity in the Indian economy has experienced an annual improvement of almost 3.25\% over 2011-12 to 2018-19 (MOSPI 2020 Table 6.3) with a GDP growth of $5.27 \%$, giving energy efficiency of about $2 \%$ per year.

In the household sector, the substitution of $40 \mathrm{~W}$ incandescent light bulbs for light emitting diode (LED) bulbs that provide the same amount of light with electricity consumption of only $7 \mathrm{~W}$ can save energy. As of 31 March 2020, the Ministry of Power's National Ujala Dashboard reported that more than 36.2 crore LED bulbs had been distributed to households in the country, with estimated savings of 47 billion $\mathrm{kWh}$ per year and emissions of $38 \mathrm{MtCO}_{2}$ per year (Ministry of Power n.d.). The appliance labelling programme, under which appliances are rated with one (least efficient) to 
five stars (most efficient) depending on their energy efficiency, has the potential to reduce energy consumption by $13-40 \%$ by 2030 (Parikh and Parikh 2016).

To promote energy efficiency, the Bureau of Energy Efficiency (BEE) was set up within the Ministry of Power in 2002 under the Energy Conservation Act of 2001. The Perform, Achieve, and Trade (PAT) Scheme sets targets for energy reduction in specific industrial units of energy-intensive industries. The Energy Conservation Building Code (ECBC), launched by the Ministry of Power in May 2007 to make commercial buildings energy efficient, has been made compulsory for the building sector in many states. Parikh et al. (2014) have projected a reduction of $131 \mathrm{MT}$ of $\mathrm{CO}_{2}$ emissions in 2030, which comprises $10 \%$ of emissions from commercial buildings. These savings are in addition to savings from energy-efficient equipment.

Energy use in the transport sector can also be reduced if a large share of freight traffic is shifted to the railway sector. To move one tonne over one kilometre, a truck consumes five to seven times the diesel a train would.

Moreover, railways have been losing their freight share, as trucks provide secure, on-time, and door-to-door service. To encourage freight movement by train, two dedicated freight train corridors are under construction: one between Mumbai and Delhi, and the other between Punjab and West Bengal. Four others are still in the planning stage. Train corridors such as these can replace freight movement by road while significantly reducing energy consumption.

Even for coal-based power, the Government of India has mandated that all new power plants should be supercritical, which means that they should generate steam at a higher temperature and pressure and use $10-15 \%$ less coal per kWh compared to subcritical plants.

\subsection{Measures to increase energy security}

Efforts to increase the domestic production of oil and gas have not been very successful; our domestic production of crude oil has ranged between 32-35.9 MT over the last 20 years (PPAC n.d.[b]). Thus, the best option at hand is to substitute petroleum products with domestic energy sources such as biofuels and/or electricity. The main thrust of government policies is the electrification of railways and the promotion of electric vehicles. Due to the cost of batteries, electric vehicles are more expensive today than conventional internal combustion vehicles. Based on what they consider realistic rates of the penetration of electric vehicles, Parikh et al. (2016) estimate that the consumption of petroleum products for road transport in 2030 will decrease only marginally. Increasing fuel efficiency norms for 
vehicles would yield a much larger reduction. Of course, the greater use of public transport and non-motorized transport such as cycling and walking could have an even larger impact.

\section{THE WAY AHEAD}

Most projections show that the substantial use of coal will continue. We can curb the growth of coal consumption with a significant reduction in the cost of solar power and batteries for storing electricity. Thus, we should have a technological mission: to bring down the costs of solar PV and batteries by $50 \%$. This will render coal power economically obsolete and keep our $\mathrm{CO}_{2}$ emissions within the $1.5^{\circ} \mathrm{C}$ global warming target (Parikh, Parikh, and Ghosh 2018) without any loss of economic growth.

If coal has to be used, then to curtail air pollution, we should insist on the installation of modern electrostatic precipitators to trap 2.5 micron particulates in all new plants as well as the retrofitting of old plants. Coal plants should have flue-gas desulphurization (FGD) and selective catalytic reduction that can substantially eliminate $\mathrm{SO}_{\mathrm{x}}$ and $\mathrm{NO}_{\mathrm{x}}$ pollution. They do, however, cost more, but the additional cost would be most likely less than the cost of the health impact of air pollution.

The COVID lockdowns have shown that air quality can improve. The use of electric vehicles, public transport, cycling and walking, clean Bharat Standard-6 fuel as well as increased vehicle fuel efficiency and can cut down air pollution in cities. We can indeed have an energy future that is clean and sustainable.

\section{REFERENCES}

Government of India. 2016. "Spreading JAM across India's Economy." In Economic Survey 2015-16, edited by Arvind Subramanian, 50-67. New Delhi: Government of India.

Ministry of Power. 2020. "National Ujala Dashboard." Accessed on March 31, 2020. http://www.ujala.gov.in/.

MOSPI. 2020. Energy Statistics 2020. New Delhi: Ministry of Statistics and Programme Implementation, Government of India. http://www.mospi.gov.in/sites/default/files/publication reports/ES 202024042 0m.pdf.

Parikh, Jyoti K., Probal Ghosh, Vinay Saini, and Rajat Puri. 2016. "Modelling Studies on Greenhouse Gas Emissions and Emissions Intensity of Indian Economy." National Conference on "Post Paris Climate Action". IRADe: New Delhi. 
Parikh Kirit S., Arunish Chawla, Chandrajit Banerjee, Anshu Bharadwaj, Indrani Chandrasekhran, Rita Roy Choudhury, Nitin Desai, Jamshyd N. Godrej, Pavan Goenka, Jagdish Kishwan, S.S. Krishnan, Ajay Mathur, et al. 2014. "The Final Report of the Expert Group on Low Carbon Strategies for Inclusive Growth.” New Delhi: Planning Commission, Government of India.

http://www.indiaenvironmentportal.org.in/files/file/low $\% 20$ carbon $\% 20$ final $\% 20 \mathrm{r}$ eport.pdf.

Parikh, Kirit S., Arunish Chawla, and Varad Pande. 2011. "Interim Report of the Expert Group on Low Carbon Strategies for Inclusive Growth.” New Delhi: Planning Commission, Government of India.

https: / / www.reeep.org/sites/default/files/Interim $\% 20$ Report $\% 20$ of $\% 20$ the $\% 20 \mathrm{E}$ xpert $\% 20$ Group $\% 20$ on $\% 20$ Low $\% 20$ Carbon $\% 20$ Strategies $\% 20$ for $\% 20$ Inclusive $\% 2$ 0Growth.pdf.

Parikh, Kirit S. and Jyoti K. Parikh. 2016. "Realizing Potential Savings of Energy and Emissions from Efficient Household Appliances in India." Energy Policy 97 (October): 102-11. http://dx.doi.org/10.1016/j.enpol.2016.07.005.

Parikh, Kirit S., Jyoti K. Parikh, and Probal P. Ghosh. 2018. "Can India Grow and Live Within a 1.5 Degree $\mathrm{CO}_{2}$ Emissions Budget?” Energy Policy 120 (September): 24-37. https://doi.org/10.1016/j.enpol.2018.05.014.

Parikh, Kirit S., Jyoti K. Parikh, Probal P. Ghosh, and Gayatri Khedkar. 2013. "Low Carbon Development Pathways for a Sustainable India." New Delhi: IRADe and WWF.

Parikh, Kirit S., Surya P. Sethi, J.L. Bajaj, Pradeep Chaturvedi, Rangan Banerjee, Prodipto Ghosh, H.C. Gupta, Anil Kakodkar, Ajit Kapadia, Amit Mitra, et al. 2006. "Integrated Energy Policy: Report of the Expert Committee." New Delhi: Planning Commission, Government of India.

Petroleum Planning \& Analysis Cell (PPAC). 2018. "LPG Profile (Data on LPG Marketing) as on 01.01.2018." New Delhi: Ministry of Petroleum and Natural Gas. http://www.ppac.org.in/WriteReadData/Reports/201802221141024777342LPG0 1Jan2018.pdf.

PPAC. n.d.(a). “Import/Export.” Last modified May 25, 2020. https://www.ppac.gov.in/content/212 1 ImportExport.aspx.

PPAC. n.d.(b). "Production.” Last modified May 25, 2020. https://www.ppac.gov.in/content/146 1 ProductionPetroleum.aspx.

Smith, Kirk R. 2000. "National Burden of Disease in India from Indoor Air Pollution." Proceedings of the National Academy of Sciences 97 (24): 13286-13293. https://doi.org/10.1073/pnas.97.24.13286. 